grants: Pfizer, Abbvie, Elea Phoenix. None of them have access to patient data., Carolina Aeschlimann Grant/research support from: Unrestricted grants: Pfizer, Abbvie, Elea Phoenix. None of them have access to patient data., Rosana Quintana Grant/research support from: Unrestricted grants: Pfizer, Abbvie, Elea Phoenix. None of them have access to patient data., Karen Roberts Grant/research support from: Unrestricted grants: Pfizer, Abbvie, Elea Phoenix. None of them have access to patient data., Carolina Ayelen Isnardi Grant/research support from: Unrestricted grants: Pfizer, Abbvie, Elea Phoenix. None of them have access to patient data., Guillermo Pons Estel Grant/research support from: Unrestricted grants: Pfizer, Abbvie, Elea Phoenix. None of them have access to patient data.

DOI: 10.1136/annrheumdis-2021-eular.1294

\section{POS1187 WILLINGNESS TO GET THE COVID-19 VACCINE AMONG PATIENTS WITH RHEUMATIC DISEASES, HEALTH WORKERS AND GENERAL POPULATION}

B. Yurttas ${ }^{1}$, B. C. Poyraz ${ }^{2}$, N. Süt ${ }^{3}$, A. Ozdede ${ }^{1}$, M. Oztas ${ }^{1}$, Ö. F. Tabak', V. Hamuryudan ${ }^{1}$, E. Seyahi ${ }^{1} .{ }^{1} /$ stanbul University- Cerrahpasa, Cerrahpasa Medical Faculty, Department of Internal Medicine, Division of Rheumatology, Istanbul, Turkey; ${ }^{2}$ Istanbul University- Cerrahpasa, Cerrahpasa Medical Faculty, Department of Psychiatry, Division of Geropsychiatry, Istanbul, Turkey; ${ }^{3}$ Trakya University Medical Faculty, Department of Biostatistics and Medical Informatics, Edirne, Turkey; ${ }^{4}$ Istanbul University-Cerrahpasa, Cerrahpasa Medical Faculty, Department of Infectious Diseases and Clinical Microbiology, Istanbul, Turkey

Background: As of January 2021 the COVID-19 pandemic has been responsible for more than 2.2 million deaths worldwide (1). Potential vaccines against COVID-19 have been developed swiftly and vaccination programs were started in many countries. Turkey agreed to use inactivated vaccine candidate, 'CoronaVac' produced by Chinese biopharmaceutical company (3). Many of our patients having a rheumatic diseases (RD) call us for permission to get vaccination, while some express their concerns about the efficacy and safety issues.

Objectives: We therefore assessed the willingness to get vaccination among patients with RD compared to health workers and a sample from general population.

Methods: A web-based questionnaire study was conducted in a cross-sectional design in 3 groups of participants: 1. patients with RD, 2. hospital workers and 3. General population. The questionnaire sought socio-demographic variables, COVID-19 related risk factors, willingness to get vaccination, and concerns and thoughts about vaccine. COVID-19 related anxiety (CAS) was also evaluated through the questionnaire.

Results: We studied in total $732(258 \mathrm{M} / 474 \mathrm{~F})$ patients with RD, $320(88 \mathrm{M} /$ $232 \mathrm{~F})$ hospital workers and $763(258 \mathrm{M} / 505 \mathrm{~F})$ individuals representing general population. Patients with RD were significantly older and less educated and spent less time using social media compared to both control groups (Table 1). CAS scores were similar between the study groups. Of the patients with RD, $29.2 \%$ were willing to be vaccinated, $19 \%$ were unwilling and $51.8 \%$ were undecided. These were similar among the general population $34.6 \%$, $23.3 \%$ and $42.1 \%$, respectively), whereas hospital workers were significantly more willing $(52.5 \%, 20.9 \%$ and $26.6 \%$, respectively) ( $<<0.0001)$. About a third in each group thought that vaccination should be obligatory. The major concerns associated with vaccine were fear from side effects, unknown scientific results and lack of confidence. Being male, older age, working in a hospital and increased anxiety levels were found to be independently associated with willingness.

Conclusion: Only about one third of the patients with RD were willing to get vaccination, which was somewhat similar to that observed among the general population. This could be due to rushed vaccine development as well as negative news on vaccines on the social media. Our study also reveals that, after almost one year after the pandemic, about $95 \%$ in all study groups did not express dysfunctional anxiety related with COVID-19.

REFERENCES :

[1] https://covid19.who.int/

[2] https://www.bloomberg.com/news/articles/2020-12-26/ turkey-signs-accord-with-biontech-for-coronavirus-vaccine
Table 1. Socio-demographic and COVID-19 associated variables, anxiety scores and willingness to get vaccination

\begin{tabular}{|c|c|c|c|c|}
\hline & $\begin{array}{l}\text { Patients with } \\
\text { RD } \\
(n=732)\end{array}$ & $\begin{array}{l}\text { Hospital } \\
\text { workers } \\
(n=320)\end{array}$ & $\begin{array}{c}\text { General } \\
\text { population } \\
(\mathrm{n}=763)\end{array}$ & $P$ \\
\hline Male/ Female, $\mathrm{n}$ & $258 / 474$ & $88 / 232$ & $258 / 505$ & 0.045 \\
\hline Age, mean $\pm S D$, years & $42.8 \pm 11.6$ & $37.0 \pm 10.0$ & $40.8 \pm 12.0$ & $<0.001$ \\
\hline Primary/middle school education, n (\%) & $225(30.7)$ & $6(1.9)$ & $28(3.7)$ & $<0.001$ \\
\hline $\begin{array}{l}\leq 1 \text { hour daily spent using social media, } \\
n(\%)\end{array}$ & $270(36.9)$ & $100(31.3)$ & $192(25.2)$ & $<0.0001$ \\
\hline $\begin{array}{l}\text { COVID }-19 \text { related anxiety, total score, } \\
\text { mean } \pm \text { SD }\end{array}$ & $1.62 \pm 3.03$ & $1.81 \pm 2.64$ & $1.55 \pm 2.71$ & 0.389 \\
\hline $\begin{array}{l}\text { COVID-19 related anxiety, cut off value of } \\
\geq 9, n(\%)\end{array}$ & $36(5.1)$ & $13(4.2)$ & $29(4.0)$ & 0.626 \\
\hline \multicolumn{4}{|l|}{ COVID-19 diagnosis in the participant ( $\mathrm{n} \%)$} & $<0.0001$ \\
\hline Yes & $104(14.2)$ & $69(21.6)$ & $70(9.2)$ & \\
\hline No & $617(84.3)$ & $248(77.5)$ & $687(90.0)$ & \\
\hline Unsure & $11(1.5)$ & $3(0.9)$ & $6(0.8)$ & \\
\hline \multicolumn{4}{|c|}{ COVID-19 diagnosis among the household or close friends, $\mathrm{n}(\%)$} & $<0.0001$ \\
\hline Yes & $460(62.8)$ & $244(76.3)$ & $435(57.0)$ & \\
\hline No & $254(34.7)$ & $76(23.8)$ & $317(41.5)$ & \\
\hline Unsure & $18(2.5)$ & 0 & $11(1.4)$ & \\
\hline Presence of any comorbid disease, $n(\%)$ & $304(41.5)$ & $67(20.9)$ & $181(23.7)$ & $<0.0001$ \\
\hline History of psychiatric disorder, $\mathrm{n}(\%)$ & $177(24.2)$ & $51(15.9)$ & $110(14.4)$ & $<0.0001$ \\
\hline \multicolumn{4}{|l|}{ Willingness to get vaccination ( $\mathrm{n} \%$ ) } & $<0.0001$ \\
\hline Yes & $214(29.2)$ & $168(52.5)$ & $264(34.6)$ & \\
\hline No & $139(19.0)$ & $67(20.9)$ & $178(23.3)$ & \\
\hline Unsure & $379(51.8)$ & $85(26.6)$ & $321(42.1)$ & \\
\hline \multicolumn{4}{|c|}{ Do you think that vaccination should be obligatory? $\mathrm{n}(\%)$} & 0.003 \\
\hline Yes & $216(29.5)$ & $113(35.3)$ & $207(27.1)$ & \\
\hline No & $277(37.8)$ & $136(42.5)$ & $331(43.4)$ & \\
\hline Unsure & $239(32.7)$ & $71(22.2)$ & $225(29.5)$ & \\
\hline
\end{tabular}

Disclosure of Interests: None declared.

DOI: 10.1136/annrheumdis-2021-eular.1435

\begin{tabular}{l|l}
\hline POS1188 & COVID-19 IN PATIENTS WITH RHEUMATIC DISEASES: \\
COMPARISON OF DATA FROM THE ARGENTINE \\
REGISTRY (SAR-COVID), WITH THE LATIN AMERICAN \\
AND GLOBAL REGISTRY (GLOBAL RHEUMATOLOGY \\
ALLIANCE)
\end{tabular}

A. A. Reyes ${ }^{1}$, G. Alle ${ }^{1}$, R. Tanten ${ }^{1}$, M. Scolnik ${ }^{1}$, E. Soriano ${ }^{1}$, G. Berbotto ${ }^{2}$, M. $\mathrm{Haye}^{2}$, M. J. Gamba ${ }^{2}$, R. Nieto ${ }^{2}$, M. García ${ }^{2}$, V. Savio², L. Gonzalez Lucero², P. Alba ${ }^{2}$, L. Takashima ${ }^{2}$, F. Risueño ${ }^{2}$, L. Casalla ${ }^{2}$, N. Cucchiaro² ${ }^{2}$ A. Bertoli ${ }^{2}$, S. Porta ${ }^{2}$, C. Maldini ${ }^{2}$, R. Gallo ${ }^{2}$, C. Goizueta ${ }^{2}$, E. Picco ${ }^{2}$, R. Quintana ${ }^{3}$, K. Roberts ${ }^{3}$, C. A. Isnardi ${ }^{3}$, G. Pons-Estel ${ }^{3}$ on behalf of SAR-COVID Registry ${ }^{1}$ Hospital Italiano de Buenos Aires, Reumatologia, Buenos Aires, Argentina; ${ }^{2}$ On behalf of SAR-COVID Registry, On behalf of SAR-COVID Registry, Buenos Aires, Argentina; ${ }^{3}$ Argentine Society of Rheumatology - Research Unit - SARCOVID Registry, Argentine Society of Rheumatology - Research Unit - SARCOVID Registry, Buenos Aires, Argentina

Background: SARS CoV-2 infection has recently burst onto the global scene and the knowledge of the course of this infection in patients with rheumatic diseases receiving immunomodulatory treatment is still insufficient. The Argentine Society of Rheumatology (SAR) designed a national registry called SAR-COVID in order to get to assess our reality.

Objectives: To identify the particular characteristics of patients with rheumatic diseases and COVID-19 in Argentina (SAR-COVID Registry), and to compare them with the data reported at the Latin American and Global level (Global International Alliance Rheum-COVID Registry).

Methods: A national, multicenter, prospective and observational registry was carried out. Patients older than 18 years, with a diagnosis of rheumatic disease and SARS-CoV-2 infection by PCR or serology, were included between August 13, 2020 and January 17, 2021. Demographic data, underlying rheumatic disease (activity of the disease, current treatment), comorbidities, clinical-laboratory characteristics of the SARS-CoV-2 infection, as well as received treatments (pharmacological, oxygen therapy / ventilatory support) and outcomes (hospitalization, mortality) were recorded. The characteristics of the 